\title{
Process Management: Increase the Ratio of Raising Heads in the Ideological and Political Theory Course----------Taking Local Universities for Example
}

\author{
Guo Qianshen \\ School of Marxism, China University of Geosciences (Beijing), Beijing, China
}

Email address:

252361843@qq.com

To cite this article:

Guo Qianshen. Process Management: Increase the Ratio of Raising Heads in the Ideological and Political Theory Course-----------Taking Local Universities for Example. Education Journal. Vol. 7, No. 5, 2018, pp. 122-126. doi: 10.11648/j.edu.20180705.13

Received: September 27, 2018; Accepted: October 30, 2018; Published: November 8, 2018

\begin{abstract}
So far, teaching of ideological and political theory is still the main channel for ideological and political education of Chinese College students. One of the most important criteria for teaching quality is the ratio of raising heads in class. It is a common problem that the ratio of raising heads in the ideological and political theory course in local ordinary university is not high. The important reason is results management mode which pays attention to the final exam results and despises the usual grades. "Despising the usual grades" means that students do not have to study hard in class. "Paying attention to final exam results" means that students only need to work hard in open book exams. Local ordinary university students mean that their learning initiative is weak. The exam is usually open at the end of the ideological and political theory course. In the final exam, it is difficult to examine the changes in students' ability and values to solve practical problems by using Marxist theory. So, the results management mode is not suit for ideological and political theory course, should turn to process management mode which focusing on the regular grade downplaying the final exam results. The regular grade should dominate which including attendance, speaking in class, practical teaching and writing learning experience and so on. The process management mode has greatly increased the ratio of raising heads in class. It is proved that this is an efficient mode.
\end{abstract}

Keywords: Ideological and Political Theory Course, The Ratio of Raising Heads, Process Management

\section{Introduction}

Ideological and political theory course plays an important role in the process of "educating and guiding students to establish the lofty ideal of communism and the common ideal of socialism with Chinese characteristics [1]". Since the implementation of "2005 plan" in Ideological and political theory course, the effectiveness of teaching has been greatly improved. However, "The ratio of raising heads in Ideological and political theory course is not high [2]", which is a big problem for teachers of ideological and political theory course in local universities. "The ratio of raising heads" refers to the ratio of students looking up at class. Generally speaking, the high "ratio of raising heads" in class indicates that the teaching effect is good. The low "ratio of raising heads" in class indicates poor teaching effect. The "ratio of raising heads" of the local college students' ideological and political courses is not high. Therefore,
General Secretary Xi Jinping stressed at the National Conference on Ideological and Political Work of Colleges and Universities in 2016 that "ideological and political theory courses should be strengthened in the process of improvement, and the pertinence of Ideological and political education should be enhanced. [3] "Find out the reasons why the "ratio of raising heads" is not high, and take pertinent measures.

One of reasons is that students fear the theoretical study of the ideological and political course. "Local ordinary universities are positioned as multi-discipline or single-discipline applied universities or colleges, aiming at serving regional economic and social development, mainly to cultivate applied talents, and in some advantageous majors or disciplines can cultivate research talents [4]". As a result, the curriculum of local colleges and universities tends to be applied, and one of the results is that college students are less interested in theoretical courses. The second reason is that 
some college students think "the ideological and political theory course is useless [5]". The third reason is that "local college students are less active in learning [6] "than students from key universities. The fourth reason lies in the result management mode of focusing on the final examination score but neglecting the regular grade. In addition, the low level of teachers' theory is also an important factor. Because "theory is not thorough, it is difficult to convince people [7]". Due to limited space, this paper does not discuss such factors as external environment, but mainly discusses the problems caused by the fourth reason.

\section{From Result Management to Process Management}

At present, the ideological and political theory course in most local universities is result management, that is, paying attention to students' final examination results. The student's total grade is composed of the regular grade and the final examination results. Generally, the ratio of the two is 3:7, and some colleges and universities are 4:6, while "a few colleges and universities are 5:5 [8]". These proportions are not well suited for ideological and political theory course. "Despising the usual grades" means that students do not have to study hard in class. "Paying attention to final exam results" means that students only need to work hard in open book exams. Local ordinary university students mean that their learning initiative is weak. In the result management of emphasizing the final examination results rather than the regular grade, the final exam is regarded as the main standard to test the course knowledge, and also becomes one of the main means to measure the teacher's teaching effect. This is not conducive to the comprehensive development of students and quality improvement, assessment results are one-sided. It is difficult to examine the changes in students' ability and values to use Marxist theory to solve practical problems. The main task of the ideological and political theory course education is to cultivate this ability and correct values. The pattern of result management makes students pay little attention to the study of courses, and they do not study hard at ordinary times. As a result, the number of students who "bow their heads" increases. Ideological and political theory course is adopted as a result of the school unified open book examination, "phubber" more, not conducive to the usual teaching management work. Therefore, result management is not suitable for ideological and political theory courses, and it is particularly important to turn to process management. Process management is to pay more attention to regular performance and weaken the final exam grade. Only by paying more attention to classroom attendance, speaking in class, practical teaching and writing of learning experience can we finish the task of ideological and political theory course education. The process management mode is a baton, guiding students to move towards the direction that the teacher hopes, so as to complete the education task of ideological and political courses in local universities and realize its educational function. The author has been engaged in ideological and political education for many years and explored a set of effective process management model. Final evaluation $=$ usual score of $70+$ final score of 30 . Usual performance $=$ attendance 10 points + speech in class 35 points + practical teaching 20 points + learning experience 5 points. This model changes the status quo that students can pass without hard work.

\section{Preparation for the Process Management Mode}

During the first ideological and political theory class, the teacher informs the process management mode, selects a teacher assistant and set up learning teams. First, inform the process management mode. Emphasizing the dominance of grades at ordinary times, the days of final-term papers being a volume are over. There is no alternative but to try hard at ordinary times. Second, select a teacher assistant. The main function of teacher assistant is to check on the work attendance, record the result at ordinary times, and set up the bridge between the teacher and students. The assistant must be fair and impartial. The assistant finishes his own work, will get 70 full marks, get zero points for favoritism. For example, if a classmate in class is absent from class and the assistant is intentionally concealed, do not record, this belongs to favoritism corrupt. A fraud will get 0 points, which helps to maintain discipline seriousness. Assistant selection is in the form of a show of hands, who raises his hand first. To be fair, the assistant does not join small teams of learners. Third, set up small learning teams. In view of the large number of ideological and political education classes in local universities, most of which are between 80 and 100, and some even exceed 100 , it is necessary to set up small teams for learning. Setting up a team is conducive to classroom management and cultivating students' teamwork spirit. Each class is roughly divided into 10 learning teams. 8 to 10 members per team. Team up immediately in class. Students are free to form teams. Each small team recommends a captain. The duty of the captain is to help the assistant to check attendance, urge the team members to attend class on time, raise their hands to speak in class actively, and assign practical teaching tasks. Fixed the seats of each study group and adjusted once a month as a team. In order to embody the team spirit, the team needs to have its own team name, slogan and commitment. Each team turns the information into a form and hands it to the assistant for attendance and for recording presentations. Each small team is preceded by a desk calendar brand with team information.

\section{Implementation of Process Management}

\subsection{Attendance}

Just as Marx pointed out that "the first premise of all 
human history is undoubtedly the existence of living individuals [9]", the first premise of improving the " rate of raising heads" of the classroom is undoubtedly the existence of students in the classroom. attendance is a powerful tool to ensure that students arrive at class, especially at local universities, because their learning initiative is weaker than that of students at key universities. Attendance is "chicken ribs" for the ideological and political theory teachers in most local universities. No attendance, low attendance. The attendance is too frequent and time consuming, which is easy to arouse students' aversion. Occasional attendance is no deterrent. With teacher assistant, fixed seats and captains, attendance became a breeze. When the bell rings, the assistant records the students who rush to class. Then, the assistant looks around to see if there is any vacancy in the fixed position of each small team. If there is any vacancy, ask the captain to submit the list of absenteeism, and the attendance can be completed in two or three minutes. Five minutes before class, the assistant needs to look around each team again. Attendance accounts for 10 points, 0.5 points are deducted once for being late and 2.5 points are deducted once for playing truant. Five times of missed classes directly into the make-up examination list. Playing mobile phones in class is equivalent to playing truant. Other people in the small team where the mobile phone is played will lose 0.5 points each student, because they do not remind the student and reflect team spirit. Before the class, the captain collects the cell phones of the team members and keeps them. After two classes, they will be sent back. There are three things the teacher needs to do in attendance. The first thing is that the teacher reminds the captain before class to collect the cell phone for safekeeping. Practice has proved that students who take away their mobile phones have a very high "ratio of raising heads". Second, we should firmly deal with students who play with their mobile phones in class, as an example. The third is two minutes before the end of class to announce the day attendance results for students to check. The teacher praises the team that attends class on time and criticizes the team with low attendance. This kind of attendance makes the vast majority of students carry on unconsciously, does not waste time. It is simple and effective. As can be seen from Table 1, the students in the process management class are much lower than those in the result management class in terms of lateness, early leaving rate and being absent rate.

Table 1. Comparing the Attendance Rates of Students under two Management Modes.

\begin{tabular}{|c|c|c|c|c|}
\hline Class percent & Arriving late & leaving early & being absent & total \\
\hline results management mode & $15 \%$ & $5 \%$ & $10 \%$ & $30 \%$ \\
\hline Process management mode & $1 \%$ & $1 \%$ & $0 \%$ & $2 \%$ \\
\hline
\end{tabular}

\subsection{To Speak in Class}

Class presentations are conducted as teams. The teacher calls the team name instead of the classmate name in class. Students hold a card when they need to speak in class. The teacher can see the team name on the sign directly. Multiple teams to raise the CARDS, the first team to lift the CARDS will speak. If two or more teams hold CARDS at the same time, the team who has not spoken in this class will be given priority. At the same time, it is stipulated that each student can only speak once in a class (45 minutes). If all other students cannot answer, this restriction is not applicable. The teacher gives the team a card to answer the questions correctly. After class, the captain collects the cards and gives them to the teacher's assistant to register the total number of cards. The number of cards to be declared in the second class arouses the desire of the team to "fight". At the end of the semester, the final class announces the total number of cards and the ranking of each team and uses this as the scoring criteria. Class presentations accounts for 35 points, with the top player getting a full score of 35 . Other teams calculate their scores basing on the number of cards the top player to get. For example, if the first player has a total of 70 cards, each card is worth 0.5 points. All team members score the same. This is consistent with the principle of deducting points for absenteeism in attendance. In this link, the teacher needs to grasp the following three details. The first thing is to protect the enthusiasm of each team and narrow the gap between the cards of each team. Since each team is a free combination, there may be a strong combination and some teams are weak. As a result, weaker teams with fewer cards are given more opportunities to speak. On this basis, the teacher needs to motivate these teams to compete. The second is to select cards carefully. Use out-of-town cards instead of local ones, so that students don't have to make up the number of cards they buy. Third, ask questions carefully. Take the time to ask questions. For example, if students are found to be in low spirits during lectures, ask more questions to boost morale. Ask questions well. Teach students in different majors according to their aptitude. Students majoring in liberal arts with good foundation, such as Chinese and economic management, need to ask more difficult questions. For students with poor liberal arts foundation, such as music, art and sports majors, it is better to ask less difficult questions. As can be seen from table 2, more students in the process management class ask questions from teacher to students, from students to students and from students to teachers than in the result management class. 
Table 2. Comparing the Number of Questions in a Class under two Management Modes.

\begin{tabular}{llll}
\hline Class numbers & Teacher asks students questions & students ask students questions & Students ask teacher questions \\
\hline results management mode & 5 & 0 & 1 \\
Process management mode & 10 & 5 & 6 \\
\hline
\end{tabular}

\subsection{Practical Teaching}

Practical teaching is a form of social practice. Through the form of social investigation, students learn about practical problems and try to interpret them with Marxism theory. The teaching activities show the achievements in practice in class. Each team can choose some of the teaching topics provided by the teacher, or they can choose independently. The premise is to use the principles in the textbook to explain. Teachers put forward specific requirements for practical teaching (20 points). the first thing is the questionnaire (3 points). No less than 100 paper questionnaires and no less than 200 electronic questionnaires. The second is video (2 points). Ask each team to make video for 4-5 minutes. Third, make PPT courseware (5 points). The most basic principles are clarity and logic. Fourth, select the speaker (3 points). Candidates are expected to be loud and speak standard mandarin. Fifth, control the class time (2 points). The teaching time is 20 minutes. Sixth, interaction in the form of questions (1 point). People in this small group can't answer questions. Students who answer the questions correctly can also get a playing card. Seventh, the teaching accounts for 4 points. After a team conducts practical teaching, other team members make comments. Comments are the same as class speeches, they can get cards. Finally, the teacher makes a summary comment and gives the score. The teacher should pay attention to practical matters. During the making of courseware by students, teachers should put forward suggestions to revise the courseware. The preparation of the questionnaire, the issuance of the questionnaire, the making of video, the making of PPT courseware and the main presentation all require the participation of team members, which improves the teamwork ability and also exercises the teaching ability. Practical teaching enables students to learn to think from others. Through their own classes, students have a deep understanding of the hard work teachers engage in. Practical teaching for students is usually arranged after week 8 , so that students can learn teachers' teaching skills and get fully prepared. As can be seen from Table 3, the student team of the class that implements the process management mode is much higher than the student team that implements the result management mode in terms of the proportion of questionnaires, homemade videos, clear courseware and loud teachers.

Table 3. Comparing the Effect of Practice Teaching under two Management Modes.

\begin{tabular}{lllll}
\hline Class percent & Questionnaire & Homemade video & Clear PPT & Loud speaker \\
\hline results management mode & $40 \%$ & $20 \%$ & $60 \%$ & $70 \%$ \\
Process management mode & $90 \%$ & $50 \%$ & $90 \%$ & $90 \%$ \\
\hline
\end{tabular}

\subsection{Writing Learning Experience}

Learning experience is an important channel for teachers to obtain students' feedback information, which is necessary for improving teaching in the future. Writing learning experience (5 points) is at the last class of the semester. Each student writes their learning experience on an A4 sheet of paper. The first line of learning experience should include semester, course, class, name, student id and team name. The main content of learning experience includes three aspects. First, the students summarize their own ideological changes since a semester. Second, point out the advantage and disadvantage of teacher's teaching. Third, give advice to the teacher. Score 5 points for original and full A4 paper. Other discretionary points. All plagiarism will not be graded. It's a good way to be honest with students education. In order to let the student write the study experience carefully, the teacher needs to do the following work. First, the teacher carries enough A4 paper. Second, the teacher takes Bookbinding the learning experiences of students in previous years to the classroom, so that students know that the teacher is serious. Third, students' comments on teachers' shortcomings do not affect students' final evaluation. The student's regular grade is all transparent, the student can calculate by themselves. Therefore, there is no need to worry about affecting their grades. As can be seen from Table 4, the students in the class with the process management mode are much more satisfied with the classroom than those in the class with the result management mode.

Table 4. Comparison of Students' Satisfaction with Teaching under two Management Modes.

\begin{tabular}{llll}
\hline Class percent & Very satisfied & satisfied & dissatisfied \\
\hline results management mode & $5 \%$ & $40 \%$ & $55 \%$ \\
Process management mode & $20 \%$ & $70 \%$ & $10 \%$ \\
\hline
\end{tabular}

\subsection{Final Examination}

The final examination is still necessary as a means to test students' mastery of knowledge and urge them to study.
However, most of the local universities take the open-book examination at the end of the ideological and political theory course, which results in the disappearance of the function of urging students to learn. Therefore, it is imperative to reduce 
the proportion of final exam scores. The final exam will be reduced to only 30 points. To prevent students from ignoring their final grade, set a baseline. Students who scores less than 10 points on the 30-point final paper are placed on the make-up list. As can be seen from Table 5, the passing rates of the two management modes are almost the same, but the students who implement the process management mode have a much higher rate of excellence in the examination than those who implement the result management mode.

Table 5. Comparison of Students' Final Examination Results under two Management Modes.

\begin{tabular}{llll}
\hline Class Final exam & Failing rate & passing rate & excellent rate \\
\hline results management mode & $20 \%$ & $80 \%$ & $5 \%$ \\
Process management mode & $10 \%$ & $90 \%$ & $35 \%$ \\
\hline
\end{tabular}

\section{Conclusion}

To sum up, process management is a good measure to improve "the ratio of raising heads" of ideological and political theory course. The ratio of raising heads for students that implements the result management mode is $30 \%$, while the ratio of raising heads for students that implements the process management mode is $89 \%$. The most important factor of implementing the process management mode is "that the teachers are consciously engaged in the ideological and political theory course education and teaching, with a strong sense of enterprise and a high sense of professional pride. [10]"

\section{References}

[1] Xi Jinping, Adhering to the Road of Socialist Education Development with Chinese Characteristics, Cultivating Socialist Builders and Successors with All-round Development of Moral, Intellectual, Physical, and Labor [N]. People's Daily, 2018-09-11(1).

[2] Chen Baosheng, Press Conference at the Fifth Session of the Twelfth National People's Congress: Chen Baosheng's Response to "Education Reform and Development" [N]. China Education Daily, 2017-03-13 (1).

[3] Xi Jinping emphasized that ideological and political work should be carried through the whole process of education and teaching at the National Conference on Ideological and political work in Colleges and universities to create a new situation for the development of higher education in China $[\mathrm{N}]$. People's Daily, 2016-12-09(1).

[4] Sun Feng, On the orientation of local colleges and universities and $[\mathrm{J}]$. Heilongjiang Researches on Higher Education, 2009(6), pp. 26-28.

[5] Sun Zongwei, Yue Yingxin, Is there no legitimacy in the ideological and political theory course in Colleges and universities? Comment on several queries: [J]. Journal of Ideological and Theoretical Education, 2016, (6), PP. 99-104.

[6] Ma Shuqin, Research and Practice on the Development and Utilization of Regional Curriculum Resources in the Teaching of Ideological and Political Courses in Local Universities__ at Tonghua Normal University[J]. Modern Communication, 2017 (7) pp. 1-2.

[7] Xi Jinping, Speech at the 95th anniversary congress of the Communist Party of China [N]. People's Daily, 2016 - 07 - 02 (2).

[8] Zhang Shang-bing, Three dimensions of increasing ratio of raising heads of Ideological and political theory courses in Colleges and Universities under the new situation [J]. Higher Education Form, 2018(1). pp. 18-21.

[9] Selections of Marx and Engels. Volume 1[M]. Beijing: people's publishing house, 2012, pp. 146.

[10] Wang Xueling, On the Basic Qualities of Ideological and Political Theory Teachers [J]. Journal of Ideological and Theoretical Education, 2006 (1), pp. 18-22. 